\title{
原発性橋出血20例の臨床的検討
}

臨床症状，CT像，脳波所見と予後との相関について

桑原 敏・太田 桂二*・上田 徹** $\cdot$ 山根 冠児・上村 喜彦・高橋 勝

\section{Clinical Study of 20 Cases of Primary Pontine Hemorrhage}

With Special Reference to Correlations between Clinical, Computed Tomographic, and Electroencephalographic Findings and Outcome

\author{
Satoshi Kuwabara, Keiji Ohta*, Tohru Ueda**, Kanji Yamane, Yoshihiko Uemura \\ and Masaru TAKAHASHI
}

Department of Neurosurgery, Matsue Red Cross Hospital, Matsue; *Department of Neurosurgery, Hiroshima University, Hiroshima; **Department of Neurosurgery, Kyoto University, Kyoto

\begin{abstract}
Twenty cases of primary pontine hemorrhage $(\mathrm{PPH})$ were diagnosed by $\mathrm{CT}$ scan over a period from June 1979 to March 1982, and were treated conservatively. They were classified into four types according to their outcome. Five cases in Type I showed a full recovery or could resume most activities (ADL I or II). The initial clinical picture of this type was characterized by alertness, no disturbance of autonomic function, and mild hemiparesis. CT scan demonstrated a small hematoma which was localized in the unilateral region or midportion of the pontine tegmentum. In four cases, the largest diameter of the hematoma on a transverse section through the pons was less than $20 \mathrm{~mm}$, and its extension was limited to 2 slices, (each $10 \mathrm{~mm}$ in width). EEG performed on two patients were normal. Three cases of. Type II recovered to daily life partially assisted (ADL III). Clinical manifestations consisted of mild disturbance of consciousness, severe hemiplegia, cerebellar signs, and minor autonomic dysfunction. Hematoma was located in the bilateral pontine tegmentum and partially involved the pontine basis. The size of hematoma was less than $30 \mathrm{~mm}$ and its extension was 2 to 3 slices. EEG performed on one patient consisted of alpha activity with some theta waves. Seven cases of Type III were severely disabled in prolonged coma or the "locked-in" syndrome (ADL IV). Their clinical findings were coma in four patients, tetraplegia in seven, decerebrate regidity in two, respiratory disturbance in two, and hypertension in three. Hematoma was located in the entire pontine tegmentum and unilateral pontine basis extending to the midbrain. The size of hematoma was less than $30 \mathrm{~mm}$ in five patients and more than $31 \mathrm{~mm}$ in two. EEG was carried out on five patients in the comatose state. Alpha-pattern coma was present in two cases and beta-coma was observed in two. All five cases of Type IV died within a few days after the onset. The clinical picture was coma, tetraplegia, respiratory failure, hyperthermia, and hypertension in all cases. Hematoma involved the entire tegmentum and basis pontis and extended to the cerebellum and midbrain. The size of hematoma was less than $30 \mathrm{~mm}$ in two patients and more than $31 \mathrm{~mm}$ in three. The sagittal extension was 3 to 6 slices. The importance of systematic investigations of the clinical, computed tomographic, and electroencephalographic findings were recognized.
\end{abstract}

Key words: pontine hemorrhage, clinical symptoms, computed tomography, electroencephalography, prognosis

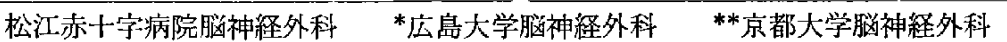

Address reprint requests to: S. Kuwabara, M. D., Department of Neurosurgery, Matsuc Red Cross Hospital, 200 Horo-machi, Matsue, Shimane 690.
}

受稿 1982年7月26日 受理 1982年 9 月13日 


\section{Iはじめに}

従来，神経放射線学的细困難であった原発性橋出血の讋 断は，CT 出現後きわぬて容易になり，血腫の部位，大き さ，進展方向に加えて脑室第破や水頭症の有無などが正確 に描写されるよらになった 血腫の確認上相まって, 日常生活が可能な例や社会復帰例 も少なくないことが判明し $4,5,7,11,23,24,30,34) ，$ 発症後早期に 重篤な意識障害と著明な自律神経障害を伴い，短期間で死 の転機をとるとされていた橋出血の概念㳊められつつ市 る.今回我々は，CT 導入後に20例の妳発性橋出血を経験 したので，これら症例の臨床症状，CT 像，脳波所見を述 べるとともに，生命予後，機能予後との相関を比較検討し たので報告する。

\section{II 対象および方法}

松江赤十字病院に扔いて，CT 導入後の1979年 6 月上り 1982年 3 月までの 2 年10力月間に経験した全脳出血症例付 183例である。このう CT で脳橋部に高吸収域索認め, 原発性橋出血と䛦断した20症例 $(10.9 \%)$ 劣対象とし，す心゙ て保存的治療を行った，発症から搬入市での時問は，院内
で発症した 2 症例を含め16症例が 3 時間以内であり，最長 7 日であった。また全例搬入直後にCTを施行した。対象 例の重症度を予後の面より，I 型(万例)：社会復州できた (ADL-1) 加，独力で日常生活可能となったもの (ADL-2), II型（３例）：意識清明であるが片麻焯や眼球運動障害，小 媨症状を有し，日常生活に他人の介助要要るもの(ADL3)，III型 (7 例)：遷延性昏睡亦るい法“locked-in”症候群 となり寝たきりの状態となったもの（発症後 3 週以後に死 亡した 1 例老含む)(ADL-4)，IV型( 5 例)：発症後数時間 から数日以内に死亡したもの，の4 型に分類した。

\section{III 結 果}

\section{1. 臨床症状亡予後}

全症例の概要を Table 1 に示した。発症年齢は27才から 82才までで，平均60.6才，男性12例，女性 8 例であった。 明ら为な高血压の既往は13例， $65 \%$ 亿認如られた。橋出 血の発症以前に他の䐉血管障害の既往をみたものは 2 例 (Case 7,8)で，各々 2 力月前， 4 年前に右被鼓出血至生じ 保存的療法にて歩行可能となっていた。意識障害で発症し たすのは 5 例であり，他注頭痛，知喾障害，嘔吖，眩鼌， 言語障害などを初発症状としたが，このうち 6 例江短時閒

Table 1 Summary of 20 cases of primary pontine hemorrhage

\begin{tabular}{|c|c|c|c|c|c|c|c|}
\hline Type* & Case & Age & $\operatorname{Sex}$ & $\begin{array}{l}\text { History of } \\
\text { hypertension }\end{array}$ & Initial symptoms & $\begin{array}{l}\text { Onset to } \\
\text { admission }\end{array}$ & $\begin{array}{c}\text { Outcome } \\
\text { (follow-up period) }\end{array}$ \\
\hline \multirow{5}{*}{ I } & 1 & 27 & $\mathrm{~F}$ & - & headache, weakness of lt. limbs & $34 \mathrm{hrs}$ & ADL $-1(2$ yrs 10 mos $)$ \\
\hline & 2 & 58 & M & + & headache, dizziness, diplopia & $20 \mathrm{~min}$ & ADL -2 (2 yrs 3 mos $)$ \\
\hline & 3 & 52 & $\mathbf{M}$ & + & numbness in $1 \mathrm{t}$. limbs, dizziness & $30 \mathrm{~min}$ & ADL-2 \\
\hline & 4 & 77 & $\mathbf{M}$ & - & headache, vomiting & 3 hrs & $\mathrm{ADL}-2$ \\
\hline & 5 & 80 & $\mathrm{~F}$ & - & numbness in face, vomiting & 2 hrs & ADL -2 \\
\hline \multirow{3}{*}{ II } & 6 & 45 & M & + & loss of consciousness & $45 \mathrm{~min}$ & $\mathrm{ADL}-3(2 \mathrm{yrs} 10 \mathrm{mos})$ \\
\hline & 7 & 67 & F & - & loss of consciousness & 7 days & $\mathrm{ADL}-3$ (2 yrs $2 \mathrm{mos})$ \\
\hline & 8 & 52 & $\mathbf{F}$ & + & headache, vomiting & $50 \mathrm{~min}$ & $(11 \mathrm{mos})$ \\
\hline \multirow{7}{*}{ III } & 9 & 76 & M & + & numbness in rt. half of body & in hospital & ADL 4 (2 yrs $3 \mathrm{mos})$ \\
\hline & 10 & 82 & $\mathbf{M}$ & - & headache, dizziness, vomiting & in hospital & $A D) L-1(2$ yrs $3 \mathrm{mos})$ \\
\hline & 11 & 45 & $\mathbf{M}$ & - & headache, vomiting, convulsion & $30 \mathrm{~min}$ & $\mathrm{ADL}-4\left(\begin{array}{ll}1 \mathrm{yr} & 1 \mathrm{mon})\end{array}\right.$ \\
\hline & 12 & 71 & $\mathbf{F}$ & + & loss of consciousness & $30 \mathrm{~min}$ & $\mathrm{ADL}-4(1 \mathrm{yr})$ \\
\hline & 13 & 39 & $\mathrm{M}$ & + & convulsion & I5 hrs & $\mathrm{ADL}-4 \quad(10 \mathrm{mos})$ \\
\hline & 14 & 69 & M & - & headache, speech disturbance & $2 \mathrm{hrs}$ & ADL-4 ( 1 mon $)$ \\
\hline & 15 & 48 & $\mathrm{M}$ & + & loss of consciousness & $17 \mathrm{hrs}$ & dead (25 days) \\
\hline \multirow{5}{*}{ IV } & 16 & 35 & M & + & weakness of lt. limbs, vomiting & 2 hrs & dead (30 hrs) \\
\hline & 17 & 80 & $\mathbf{F}$ & + & numbness in face & $50 \mathrm{~min}$ & dearl (19 hrs) \\
\hline & 18 & 77 & $\mathbf{F}$ & + & speech disturbance & I hr & dead $(25 \mathrm{hrs})$ \\
\hline & 19 & 67 & $\mathbf{F}$ & + & headache & $1 \mathrm{hr}$ & dead ( 2 hrs) \\
\hline & 20 & 65 & $\mathbf{M}$ & + & loss of consciousness & $3 \mathrm{hrs}$ & dead (9 hrs) \\
\hline
\end{tabular}

*: Types I-IV; classified according to outcome, ADL; activity of daily living 

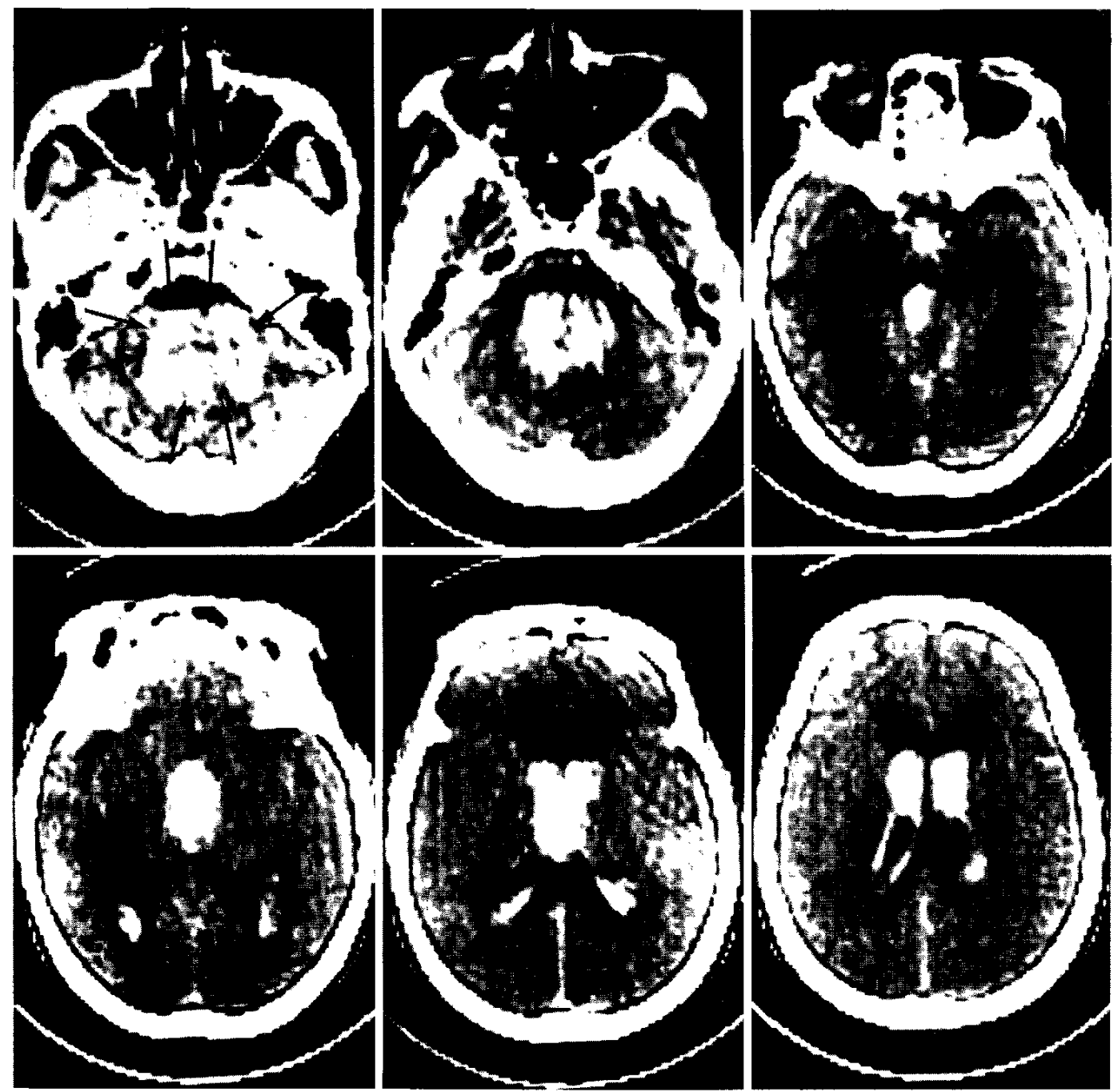

Fig. 1 Case 19. Plain CT scan showing a high attenuation mass located in the entire tegmentum and basis pontis. Hematoma extends to the cerebellum and midbrain and ruptures into the fourth ventricle. A large amount of blood is present in the dilated third and lateral ventricles. The patient died within 2 hours after admission to the hospital.

で半昏睡に移行した。一方全経過を通し，まったく意識障 害のなかったものは 5 例であった。

重症度別に入院時の意識レベル (3-3-9度方式), vital sign，神経症状，CTによる血腫部位を示したのが Table 2 である。入院時 3 䘖の重症意識障害を認めたものは，IV 型の全例， II型の 5 例， I 型の1例であり，I 型は 5 例全 例上むに，全経過を通し意識障畫はな加った。入院時に $210 / 110 \mathrm{mmHg}$ 以上の高血王を呈したものが 11 例で，IV 型法全例， III型 3 例， I 型 1 例，I 型 2 例であり,この5 ち1例を除く10例に高血圧症の眼往を認めている。むた 型の 5 例全例吕: Cheyne-Stokes, 头調性, 不規則, 中枢性 過呼吸などなんらかの呼吸異常を呈したが，他には而型の 2 例のみであった。体温が $40^{\circ} \mathrm{C}$ 以上で, 肺炎, 尿路感染症
などの合併症が否定され，中枢性過高熱と考えられたもの はIV型の3 例にみられた，又院時の運動障害法，IV型で四 肢麻㾇 3 例, 片麻痺 2 例であったが, この2 例电短時間で 四肢麻疩に移行した。型は 7 例全例に四肢麻焼を，II型 も全例に强い片麻㾇が存在した。I 型は 4 例が軽度の不全 麻脾であり，また他の1 例(Case 3)には麻猈を認めず，知 覚異常と眼球運動障害のみであった。な抬入院経過中に痤 攣寺生じたもの注 5 例，除脳硬直は 2 例であり，以ずれも IV型，III型であった。

瞳孔異常に関しては, 瞳孔不同 7 例, 縮瞳 5 例, pinpoint pupil 4 例在認めた，対光反射の消失注IV型の3 例 にのみみられ，oculocephalic reflex (OCR) の消失は IV 型 全例， III型 6 例，II 型 2 例，I 型 1 例 
Table 2 Level of consciousness, vital signs, clinical

\begin{tabular}{|c|c|c|c|c|c|c|}
\hline Type & Case & $\begin{array}{l}\text { Level of } \\
\text { consciousness }\end{array}$ & $\begin{array}{l}\text { Blood pressure } \\
(\mathrm{mmHg})\end{array}$ & Respiration & $\begin{array}{c}\text { Temperature } \\
\left({ }^{\circ} \mathrm{C}\right)\end{array}$ & $\begin{array}{l}\text { Decerebrate } \\
\text { posture }\end{array}$ \\
\hline \multirow{5}{*}{ I } & 1 & alert & $120 / 80$ & normal & 36.4 & - \\
\hline & 2 & alert & $230 \div 132$ & normal & 36.8 & - \\
\hline & 3 & alert & $232 / 110$ & normal & 36.8 & - \\
\hline & 4 & alert & $136 / 80$ & normal & 36.5 & - \\
\hline & 5 & alert & $154 / 72$ & normal & 36.3 & - \\
\hline \multirow{3}{*}{ II } & 6 & 100 & $240 \div 160$ & normal & 37.0 & - \\
\hline & 7 & 20 & $130 / 70$ & normal & 36.8 & - \\
\hline & 8 & 30 & $196 / 110$ & normal & 37.5 & - \\
\hline \multirow{7}{*}{ III } & 9 & 30 & $220 / 130$ & normal & 37.0 & - \\
\hline & 10 & 10 & $160 / 80$ & normal & 37.2 & - \\
\hline & 11 & 200 & $230 / 140$ & normal & 38.4 & - \\
\hline & 12 & 200 & $250 / 120$ & $\mathrm{C}-\mathrm{S}$ & 38.0 & - \\
\hline & 13 & 200 & $170 / 120$ & normal & 37.0 & + \\
\hline & 14 & 100 & $140 / 90$ & irregular & 36.8 & - \\
\hline & 15 & 200 & $198 / 120$ & normal & 37.4 & - \\
\hline \multirow{5}{*}{ IV } & 16 & 200 & $270 / 170$ & irregular & 41.5 & - \\
\hline & 17 & 200 & $210 / 110$ & ataxic & 41.0 & - \\
\hline & 18 & 200 & $260 / 140$ & hyperventilation & 39.8 & - \\
\hline & 19 & 300 & $230 / 130$ & $\mathrm{C}-\mathrm{S}$ & 39.0 & - \\
\hline & 20 & 300 & $242 / 140$ & $\mathrm{C}-\mathrm{S}$ & 40.1 & - \\
\hline
\end{tabular}

LR: light reflex, OCR: oculocephalic reflex, C-S: Cheyne-Stokes respiration, unil.: unilateral, bil.: bilateral,

TG: tegmentum pontis, BS: basis pontis

た，異常眼球運動は，ocular bobbing がもっとも多く7 例 を占め, ついで skew deviation 2 例, 共同偏視, one-anda-half syndrome が各々 1 例にみられた。しかし異常眼球 運動と重症度分類との閒に明睹な相関はないと考学られ た.なお ocular bobbing が諗められた症例はすべて刘光 反射は良く保たれていたが，OCR の消失していたことが 特徴的であった。脱幹症候群のらち，Millard-Gubler 症侯群が 3 例，“locked-in”症候群が 3 例，Foville 症候群 が 2 例にみられた。

\section{CT 像による血腫部位，大きさ，進展と予後}

橋中部のCT 断面上で血腫部位を検討してみると，両 側被蓋，雨側底部に及ぶ大血腫忙 4 例で，IV型 3 例，III型
1 例でむり全例死亡゙した（Fig.1，Case 19)，両側被蓋より 一側底部にのびる血腫は 6 例で，IV型 1 例，III型 3 例，II 型 2 例にみられ(Fig. 2A，Case 8)，また主として雨側被蓋 に血腫が存在するものは，IV型 1 例，III型 3 例，II型 1 例 の計 5 例であった（Fig．2B，Case 16）。片側被蓋に限局し た 3 例 (Fig. 3A，Case 5) と，被蓋中央部 の小血腫 2 例 (Fig. 3B，Case 3) 注いずれ I 型であった。全例を通し 底部のみの出血はみられなかった。

血腫の大きさ，進展範囲と予後との関係を Fig. 4 に示 した。これは落合ら ${ }^{24}$ の分類を多少修正したものである が，実物大に換算して血腫の最大径が20 mm 以下，21-30 $\mathrm{mm}, 31 \mathrm{~mm}$ 以上の 3 群に分计，進展篭囲は $10 \mathrm{~mm}$ 幅 
symptoms and location of hematoma on admission

\begin{tabular}{|c|c|c|c|c|}
\hline Convulsion & Ocular signs & $\begin{array}{c}\text { Motor } \\
\text { disturbance }\end{array}$ & $\begin{array}{l}\text { Pontine } \\
\text { syndrome }\end{array}$ & $\begin{array}{l}\text { Location of } \\
\text { hematoma }\end{array}$ \\
\hline- & anisocoria, $\operatorname{LR}(+)$ & It. hemiparesis & Foville & unil. TG \\
\hline- & $\begin{array}{l}\text { anisocoria, } \mathrm{LR}(+) \text {, } \\
\text { conjugate deviation }\end{array}$ & rt. hemiparesis & & unil. TG \\
\hline- & $\begin{array}{l}\text { miotic, LR }(+), \text { OCR }(-) \\
\text { ocular bobbing }\end{array}$ & none & & bil. TG \\
\hline- & $\begin{array}{l}\text { moderate, } \operatorname{LR}(+) \\
\text { one and a half syndrome }\end{array}$ & lt. hemiparesis & & bil. TG \\
\hline- & moderate, LR(+) & 1t. hemiparesis & Foville & unil. TG \\
\hline- & $\begin{array}{l}\text { miotic, } \mathrm{LR}(+), \mathrm{OCR}(-) \text {, } \\
\text { ocular bobbing }\end{array}$ & lt. hemiplegia & Millard-Gubler & bil. TG \& unil. BS \\
\hline- & moderate, LR(+) & It. hemiplegia & & bil. TG \\
\hline- & $\begin{array}{l}\text { miotic, } \mathrm{LR}(+), \mathrm{OCR}(-) \text {, } \\
\text { ocular bobbing }\end{array}$ & lt. hemiplegia & & bil. TG \& unil. BS \\
\hline- & $\begin{array}{l}\text { moderate, LR }(+) \\
\operatorname{OCR}(-), \text { skew deviation }\end{array}$ & tetraparesis & & bil. TG \\
\hline- & pin-point, LR $(+)$ & tetraparesis & locked-in & bil. TG \\
\hline+ & $\begin{array}{l}\text { anisocoria, } \mathrm{LR}(+) \\
\mathrm{OCR}(-) \text {, ocular bobbing }\end{array}$ & tetraplegia & locked-in & bil. TG \& unil. BS \\
\hline- & $\begin{array}{l}\text { miotic, } \operatorname{LR}(+), \operatorname{OCR}(-) \text {, } \\
\text { ocular bobbing }\end{array}$ & tetraplegia & & bil. TG \& unil. BS \\
\hline+ & $\begin{array}{l}\text { anisocoria, } \mathbf{L R}(+) \\
\operatorname{OCR}(-)\end{array}$ & tetraplegia & & bil. TG \& unil. BS \\
\hline- & $\begin{array}{l}\text { miotic, } \operatorname{LR}(+), \mathrm{OCR}(-) \text {, } \\
\text { ocular bobbing }\end{array}$ & tetraparesis & locked-in & bil. TG \\
\hline & $\begin{array}{l}\text { anisocoria, } \mathbf{L R}(+) \\
\operatorname{OCR}(-)\end{array}$ & tetraplegia & & bil. TG \& bil. BS \\
\hline+ & $\begin{array}{l}\text { anisocoria, } \mathrm{LR}(+) \\
\text { OCR }(-) \text {, ocular bobbing }\end{array}$ & lt. hemiplegia & Millard-Gubler & bil. TG \& unil. BS \\
\hline+ & $\begin{array}{l}\text { pin-point, LR }(-) \\
\operatorname{OCR}(-)\end{array}$ & tetraplegia & & bil. TG \& bil. BS \\
\hline- & $\begin{array}{l}\text { pin-point, } \mathrm{LR}(+) \\
\text { OCR }(-), \text { skew deviation }\end{array}$ & rt. hemiplegia & Millard-Gubler & bil. TG \\
\hline- & $\begin{array}{l}\text { anisocoria, } \mathbf{L R}(-) \\
\operatorname{OCR}(-)\end{array}$ & tetraplegia & & bil. TG \& bil. BS \\
\hline+ & $\begin{array}{l}\text { pin-point, LR }(-) \\
\operatorname{OCR}(-)\end{array}$ & tetraplegia & & bil. TG \& bil. BS \\
\hline
\end{tabular}

ライスの検索でスライスの枚数をもって表した。これによ れば血腫の最大径が $20 \mathrm{~mm}$ 以下で，進展が 2 スライスま でのもの橋に限局した血腫であり，I 型 4 例，II型 1 例 と機能予後良好であった。一方進展が 3 スライスに及心゙も のは全例下部中脳にまで達して㧍り，血腫の最大径は 20 $\mathrm{mm}$ 以下加ら $31 \mathrm{~mm}$ 以上の 3 群にわたり，その予後も II 型よりIV型までと広範囲でばらっきが多かった，しかし， 最大径が大きいむの汪ど予後不良になると考えられた４ スライス以上汇わるものは 5 例で，この5ち $31 \mathrm{~mm}$ 以上 の 4 例に第四腷室穿破を伴い，3例では側脳室内一の出血 の波及ならびに著明な水頭症が認められ，1例を除いて全 例死亡した。な枋橋下部のスライス面よりも尾側の断面で
高吸收域を認めたものはなく，血腫が延髄にまで達するこ とはほとんどないと考えられた。

\section{3. 脳波所見と矛後}

脳波検查注 8 例に施行され，初回の記録は発症後20時間 加ら 2 日目にわたった。内訳は I 型 2 例，II型 1 例， III型 5 例であり，IV型は短時閒で死亡したため腩波検査を行う 機会がなかった．I 型(Case 3，4) は9-11 Hz，20-40 $\mu \mathrm{V} の$ regulation の良い $\alpha$ 波が頭頂, 後頭部に優位に出現 L, $\alpha$-blocking, photic driving む認奻られ正常脳波で市っ た、 I型(Case 8) は8-10 Hz，20-40 $\mu \mathrm{V}$ の $\alpha$ 波が基礎波を なし, これに4-6 $\mathrm{Hz}, 50 \mu \mathrm{V} の \theta$ 波が両侧前頭, 頭頂部に 混入していた。而型の脑波検査時の意識レベルはいずれも 

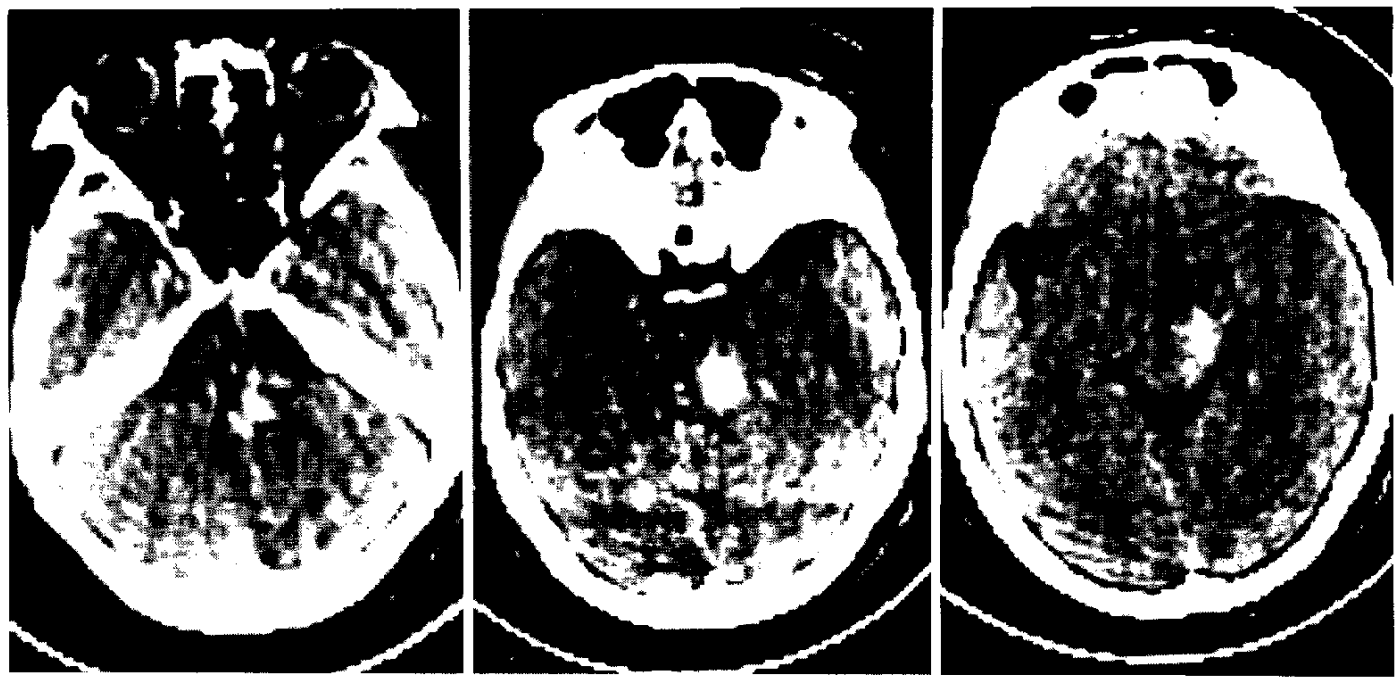

A
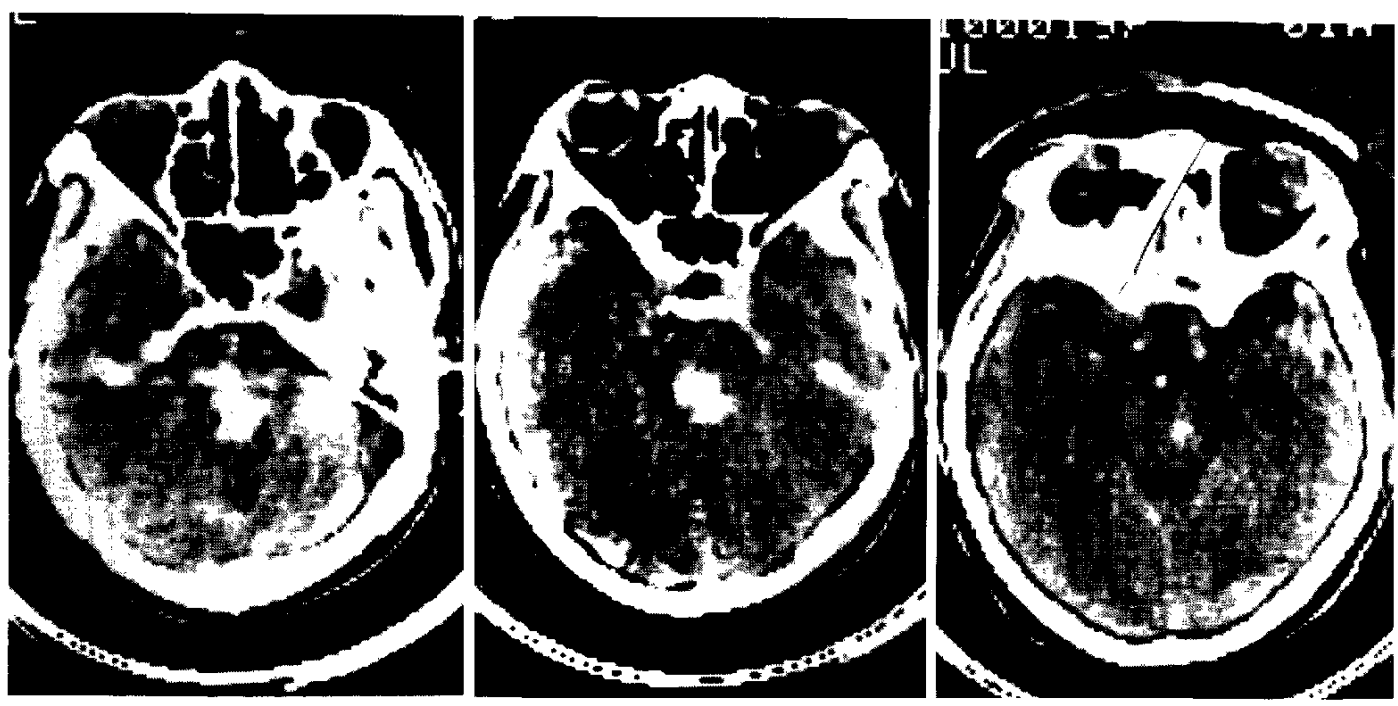

B

Fig. 2 A: Case 8. Plain CT demonstrating a highly attenuated mass located in the pontine tegmentum and right lateral portion of the pontine basis, which extends toward the right side of the midbrain. B: Case 16. Plain CT showing a mass of high attenuation in the pontine tegmentum, which extends to the midbrain.

200であった。このうち2例 (Case 12，13) は 8-11 Hz, 10$30 \mu \mathrm{V}$ の $\alpha$ 波が主体をなし，閒歇的に低電位速波が混入す る脳波で，左右差や徐波はなく，以わ中る $\alpha$-coma pattern 示した(Fig. 5A). 別の2例(Case 10，11)は19$25 \mathrm{~Hz}, 10-20 \mu \mathrm{V}$ の低電位速波が全誘導にみられ， $\alpha$ 波，徐 波はほとんどなく $\beta$-coma pattern t呈した(Fig. 6A). 他 の 1 例 (Case 15) は7-8 Hz 優位に出現し，3-6 Hz の低振幅徐波が 高頻度に混大する
脳波であった， $2 \sim 3$ 週後の脳波検查では，急性期に $\alpha$-coma 示した 2 例は，4-7 Hz, 20-30 $\mu \mathrm{V} の \theta$ 波が全諉 導にみられ，8-10 Hz, 10-20 $\mu \mathrm{V} \odot \alpha$ 波が間歇的に出現寸 る腷波に変化した(Fig. 5B)。 また $\beta$-coma の2 例は，5-6 $\mathrm{Hz}, 20-30 \mu \mathrm{V}$ の $\theta$ 波が基礎波をなし，低電位速波が散発 的に跎入する脳波に移行した(Fig. 6B). す小わら時間 の 経過とともに diffuse slowing の傾向が強くなったが，いず れも左右差は堗めなかった。 


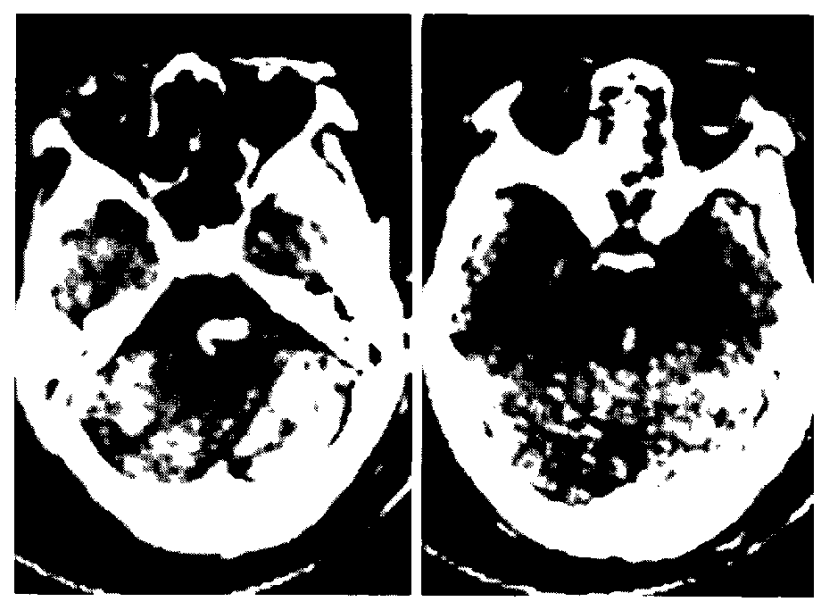

A
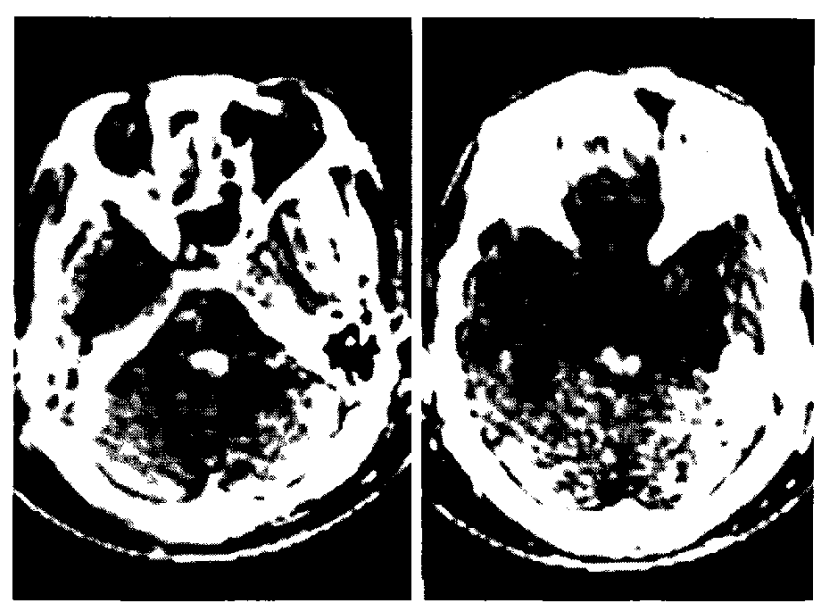

$\mathrm{B}$

Fig. 3 A: Case 5. Plain $C{ }^{\prime} \Gamma$ showing a small hematoma, which located in the right pontine tegmentum. B: Case 3. Plain CT demonstrating a small high density area located in the midportion of the pontine tegmentum.

\section{IV 考 察}

原発性橋出血㳊関する従来の報告は，その大多数が剖検 を基盤とした 臨床病理学的研究である $8,2,13,28,29,31,32)$.こ れに上れば発生嚬度は全脳出血の6 22\%，平均 $10 \%$ 前後 と考えられ，この5ち約70\%に高血圧の既往がある。発症

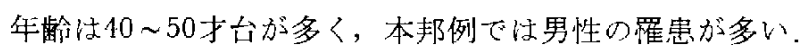

これらの結果は，CTにより診断された我々の症例におい てもほぼ同様であった。

一方臨床症状として，発作後早期の重篤な意識障害，四 肢麻痺，瞳孔異常に加えて，呼吸障害，著明な高血圧，中 枢性高熱, 頻脈などの自律神経障害があげられ，急速に死 の転州をとることが特徵とされていた机名, 13,28,29,31,32). しか

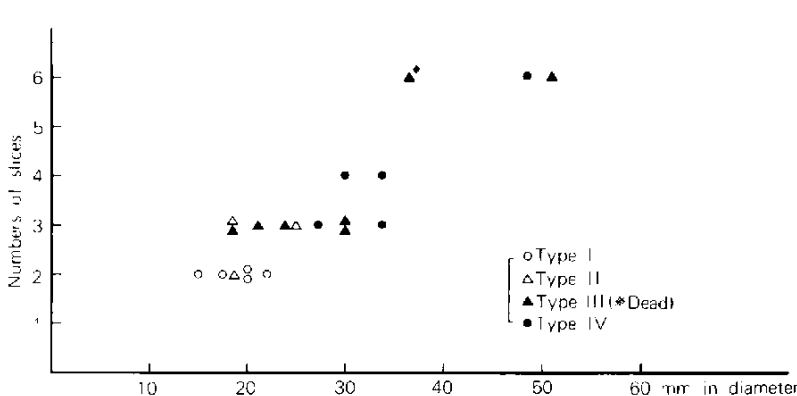

\begin{tabular}{|c|c|c|c|c|c|c|}
\hline $\begin{array}{l}\text { Exteris on } \\
\text { sizeimmi isl (es) }\end{array}$ & 1 & $?$ & 3 & 4 & 5 & 6 \\
\hline$<20$ & & $\begin{array}{lll}0 & 0 & 0 \\
0 & 8\end{array}$ & $\Delta$ & & & \\
\hline $21 \sim 30$ & & 0 & 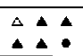 & $\cdot$ & & \\
\hline$>31$ & & & $\bullet$ & $\cdot$ & & $\therefore \wedge$ \\
\hline
\end{tabular}

Fig. 4 Correlation between size and extension of the hematoma and outcome. The size of the hematoma identified by CT is divided into 3 groups (less than $20 \mathrm{~mm}$, between $21 \mathrm{~mm}$ and $30 \mathrm{~mm}$, more than $31 \mathrm{~mm}$ ) on a transverse section through the pontine level. The sagittal extension of the hematoma is shown by numbers of slices (10 mm in width). Types I-IV are the same as in Table 1.

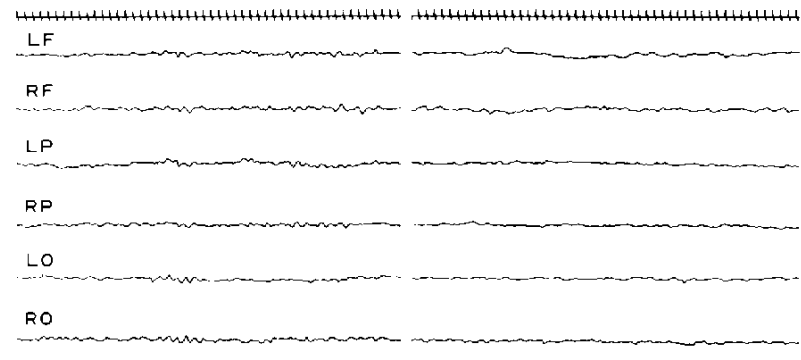
$\underline{L}$

A

Fig. 5 A: Case 13. Electrocncephalogram (EEG) taken 20 hours after the onset, when the paticnt was unresponsive to noxious stimuli. The record consists of alpha activity ranging from $10 \mu \mathrm{V}$ to $30 \mu \mathrm{V}$ and 8 to 10 herz with some low voltage fast activity. B: EEG taken on the 14th hospital day without further change in his neurological status. The record contains low voltage theta waves occasionally interrupted by short bursts of alpha activity.

し神経放射線学的検查の routine として CT が導入されて 以来，他の検查法では到底不可能であった小血腫も鑑別可 能となり，臨床症状执よび予後に関して従来の考えと著し い相違をみるに至っだ,7,11,23,24,30,34).

\section{1. 臨床症状と予後との相関}

我々のIV型に双られるごとく，ictal onset で 3 桁の重篤 な意識障害，四肢麻瘦，著明な自律神経障害を伴い，加え 


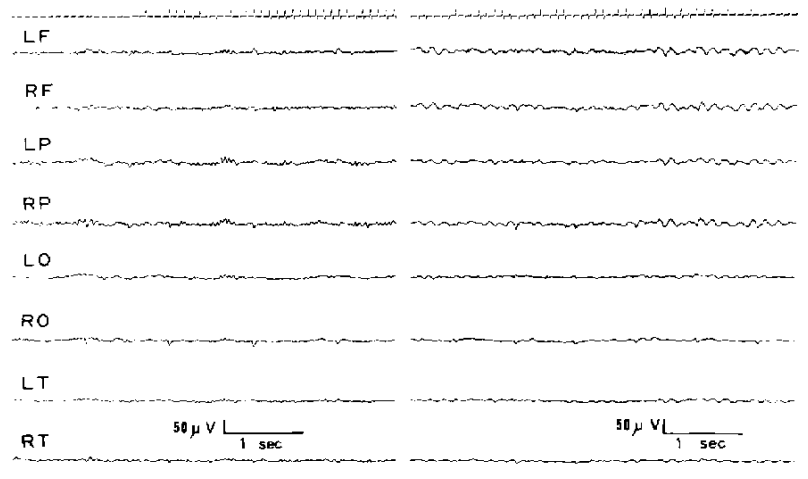

A

B

Fig. 6 A: Case 11. EEG taken on the second hospital day, with the patient in coma. The record was dominated by a high frequency low voltage activity in all leads. B: EEG taken on the 25th day after the insult, when his neurological state had remained unchanged. The record contains 5 to 7 herz, theta activity of up to $30 \mu \mathrm{V}$ in the frontoparietal areas.

て pin-point pupil，対光反射の消失が諗められる例はきわ めて生命予後不良であった。これらは過去多数の報告例と 同様の典型的な臨床症状を有して招り，以かなる治療化よ っても救命しえない症例と考えられる。とこがー方では I 型のごとく，保存的治療汇よりほ上んど神経症状を残す ことなく回復する例が比較的多い，本藤ら ${ }^{11}$ は 15 例 中 5 例, Zuccarello ら ${ }^{34)}$ は18例中 5 例，我々は20例中 5 例に認 めた。こ机らに注ぼ共通寸る臨床症状としては，数日ない し数週間の progressive あるいは two stage evolution の病 歴を有し，意識障害はまったくないかあっても軽度であ る、また不全麻瘦や脳神経障害を認好て自律神経障害は なく，高血圧の概往のない例怔多い，中島ら ${ }^{23}$ は良好な予

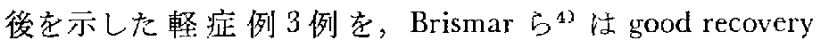
を呈した 2 例を benign brainstem hematoma として報告し ている。CT 出現前にこれら軽症例の報告がみられなかっ た理由は，剖検で立証された症例にのみ橋出血の診断が与 えられ，予後の重篤性が強調されすぎたこと，CT 以外の 検查法では小血腫の確定診断が不可能であることにより， 脳幹梗塞, ク王膜下出血, 多発性硬化症, 脳幹脳炎, 脳幹 部腫瘍などと診断されていたためと推定される1,2,14-16， 21,27). 以上の重症例と軽症例の閒には，卭型， II 型に示さ れるよらに，生命予後江良好であるが機能予後不良の群が ある。II型で注I型に比し白律神経障害が軽度であること が生命予後良好の示標上なり，また脳神経障害，錐体路症 候，小脳症状の程度の差が機能予後の上で I 型と II 型との 差を決定する因子になると考えられる．田中ら ${ }^{300}$ も高血圧 性橋出血67例㕝短期死亡例之長期生存例に分類し，入院時
の意識状態, 運動障害, 眼症状, 自律神経症状などに著し い差異がみられたと報告し，臨床症状と予後との関連につ いて我々と注ぼ同様の見解を述べている。

\section{CT 像と予後との相関}

血腫部位に関しては， $\mathrm{I}$ 型が両倒被蓋，両㑬底部を占め る大血腫，III型，II型が両側被蓋より一側底部に及ぶ血 腫，I 型は片側被蓋か被蓋中央部に限局する小血腫に大別 できよう。

血腫の大きさ, 進展に関しては, 最大径が $20 \mathrm{~mm}$ 以下 で，進展が 2 スライスまでの症例は機能予後良好と判断で きる，一方 $31 \mathrm{~mm}$ 以上で 4 スライス以上に及ぶものは，生 命予後不良と考光られた。 しかし，進展加3スライスまでの 9 症例の予後は多彩であり，一般には血腫の大きいものは ど予後不良上なる傾向が認められた。さらに発症からCT 施行までの時間む関与していると推定され，大多数の症例 が発症後 3 時間以内で CT が行われており, CT 施行後 急激な臨床症状の昰化を生じた 4 例では，血腫の増大が以 後も進行したためと考えられる。落合ら ${ }^{24}$ は，血腫の拡が りが实測值として $1 \mathrm{~cm}$ 以下の症例の生命予後は良く, 1 $\mathrm{cm}$ 以上の症例の予後は不良であり，意識障害の程度や 生命予後とは非常によく相関していると述べている。田 中ら ${ }^{303}$ 壮 CT 所見より massive, basis tegmentum, tegmentum 03 type に分類 $L$, massive type 的短期死亡例, basis tegmentum type 泩生存しても機能予後は不良, tegmentum type 注全例長期生存例で之の機能予後は 良好 であったと報告している。步た中島ら ${ }^{22)}$ は長期生存群では 血腫恰橋に限局し, 延葡, 中脳, 視床下部領域一の進展破 壞㤌なく，第四脳室へ穿破していても他の脳室采や脳槽一 の血腫充満はないと述べている，Zuccarello ら ${ }^{34)}$ は予後良 好な brainstem hematoma $と$ 予後不良の hemorrhage に区 別し，両者は CT 像により明膫に爁別できると述べてい る。すなわち hematoma の場合は，境界鮮明な eccentric high density lesion として桦写され，主として被蓋部に限 局し，䑈室穿破や脳室桩大は生しない. Hemorrhage の場 合は橋，中脳にびまん性，対称性の出血が認められ，時々 大脳脚や小脳脚古令む nervous projection pathways し，脳室穿破や腷室拢大を生じることが多いとしている。 我々の症例に抒いてもCT 所見と予後上は比較的上く 相関して拉り，血腫部位，大きさ，進展範国の検討が-予後 判定の指標になりらることが示唆された。

\section{3. 脳波所見亡予後亡の相関}

急性の脳幹障害の初期に，昏睡状態にもかかわらず，覚醒 時化類似した $\alpha$ 波 ( $\alpha$-coma) や低電位速波（ $\beta$-coma) 示 す脳波を生じるこはすでに数多く報告されているる3, $12,17,18,25,33)$. $\alpha$-coma $の$ 患者の病巣は pontomesencephalic 
junction のレベルかそれより尾側に存在し， $\alpha$-pattern 在 生じる神経集団が，この部位上りる吻側に存在することが 示崚されている6,18,33). Westmoreland $ら^{33)}$ 法 $\alpha$-coma の 患者の病変が中脳や視床に及んでいる場合です主として一 側性であることから， $\alpha$-pattern の脳波を維持寸るために は，少なくとも中脳被蓋の平分が回避されれば十分である と述べている，また脳幹病変を有する彼らの8症例恃全例 死亡し， $\alpha$-coma は生命予後不良を示すと指摘している。

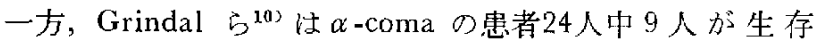
し，しか⿻驿度の神経脱落症状のみであるこ上より， $\alpha$ coma が必ずしも予後不良を意味しないと述心゙ている. し 加し彼らの場合，生存例の大多数は電撃症，薬物中毒など による呼吸停止の患者であり，脳幹障害(梗塞) 仗 1 例のみ であった。

$\beta$-comaに関して法，Kaada ら ${ }^{12)}$ が橋の上・中部を占 め中媨下部に達する出血例を，大友ら ${ }^{25}$ は椎骨脳底動脈血。 柽症打よび徨環不全の3 例を，古和田ら ${ }^{17}$ は橋中部で両側 被蓋を占める出血と考它られ長期生存した 1 例を報告して いる。 Batini ら”動物実験で midpontine pretriecminal preparation 施行後，覚醒定示唆する低電位迩波上胧球連 動が出現すること交諗めている。

我々の場合， $\alpha$-coma を示したIII型の 2 例は現在遷超性 想腄の状態であり， $\beta$-comaを示した他の 2 例は，四肢麻 痺，下部脳神経障害のため寝たきりの状態であるが，意識

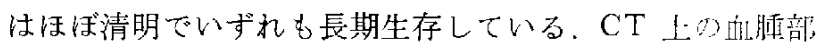
位，淮展範囲に関して両者の相違を明確に区別するこ上は できなかった。しかし両者とも橋の中・上部両側被蓋の障 恝法存在したが，中脳レぶルでは被蓋の半側以上は回避さ

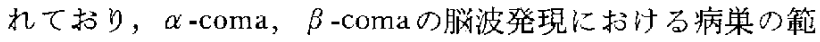
囲汢，諸家の報告6,12,17,18,25,33) と一致すると考えられた。

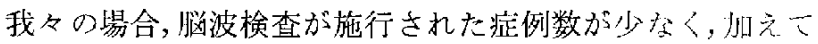
短期間で死ししたIV型の脳波は得られていないしたがっ て脳波所見より予後判定を行らことは困難であるが， $\alpha$ coma， $\beta$-coma pattern を諗めた症例でも長期生存可能 で，必ずしす生命予後不良とは言えず，また意識障害の回復 は $\beta$-coma を示した症例のほらが良いと思われた。 大友 ${ }^{20)}$ も脳波 pattern 加意識障害を分類し，重篤度は一般的汇 $\alpha$-coma $\geqq \delta$-coma $>\beta$-coma >spindle coma だあると推定 している。

脳波が徐波化する機転として，宮崎 ${ }^{19)}$ は病変が下部脳幹 上り中脳へと進展する場合を, 中島ら ${ }^{23}$ 注血腫刲辺浮腫が 中腷レベルに及ぶ時点に生しる上述べ，祭永ら ${ }^{18}$ は血堙に よる重篤な閉寒性水頭症で脳浮腫をきたし，人脳皮質が障 害されることをあげている，我々の症例においても，発症 $2 \sim 3$ 週後の畄波では $\alpha$-coma， $\beta$-coma 足した 4 例 と
もに diffuse slowing 認めたが，これは二次的な循環，代 謝障害が巾脳のみならず大脳皮質に広範に及んだことがそ の機序の1つと推察さ扎る

\section{$\mathrm{V}$ ま め}

保存的治療在施行した原発性橋出血20例の予後を4 型に 分類し，急性期の臨床症状， CT 像，脑波所見と比較検討 した.

1. 発症後早期に重篤な意識障害, 四肢麻痺, 著明な自 律神経障害が認められた 5 例は，短期間で全例死亡し絶対 的予後不良であった。

2. 全経過堂通し意識清明で，不全麻㾝や脳神経障害を 誑めても自律神経障害のない5例は, 日常生活可能か社会 復帰でき，機能予後良好であった。

3.上䛉重症型と軽症型の間に，長期生存可能であるが 雴たきりとなった 7 例と，意識清明であるが日常生活に他 人の介助を必要とした 3 例が存在した。自律神経障害が軽 度であることが生命予後良好の示標上なり，脳神経障害， 㧱体深痽倠，小脳症状の程度の差が機能予後老決定する因

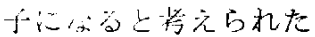

4. CT 像にて, 両側被蓋, 両側底部を占める血腫で, その最大径が $31 \mathrm{~mm}$ 以上, 進展が10 mm幅で 4 スライス以 上に及ぶ例は生命予後不良であった。一方，片側被蓋か， 被蓋中央部の小血腫で $20 \mathrm{~mm}$ 以下，2 スライスまでの例は 機能予後良好であった。

5. 怨性期の脳波で $\alpha$-coma， $\beta$-coma を示した例でも 長期生存可能であり，意識障害の回復は $\beta$-coma を呈した 例の方が良いと思われた。また譄波が徐波化する原因とし て，二次的な循環，代謝障害が，中脳去含め大脳皮質に広 範に及ぶことがその機序の1つと推察された。

6. 以上より，原発性橋出血の生命予後，機能予後の半 定に，急性期の臨床症状， CT 像，脳波所見の総合的検討 が重要であると考えられた。

本論文の要旨は, 第 7 回日本檤卒中学 会 総会(1982年 5 月, 弘 前)にて発表した。

\section{文献}

1) Abroms IF, Yessayan L, Shillito J, Barlow CF: Spontaneous intracerebral haemorrhage in patients suspected of multiple sclerosis. $J$ Neurol Neurosurg Psychiat 34: 157-162, 1971

2) Arseni C, Stanciu M: Primary haematomas of the brain stem. Acta Neurochir (Wien) 28: 323-330, 1973

3) Batini C, Moruzzi G, Palestini M, Rossi GF, Zanchetti A: Effects of complete pontine transections on the sleep- 
wakefulness rhythm. The midpontine pretrigeminal preparation. Arch Ital Biol 97: 1-12, 1959

4) Brismar J, Hindfelt B, Nilsson $O$ : Benign brainstem hematoma. Acta Neurol Scand 60: 178-182, 1979

5) Burns J, Lisak R, Schut L, Silberberg D: Recovery following brainstem hemorrhage. Ann Neurol 7: 183-184, 1980

6) Chase TN, Moretti L, Prensky AL: Clinical and electroencephalographic manifestations of vascular lesions of the pons. Neurology 18:357-368, 1968

7) Cioffi FA, Tomasello F, D'Avanzo R: Pontine hematomas. Surg Neural 16:13-16, 1981

8) Dinsdale HB: Spontaneous hemorrhage in the postcrior fossa. Arch Neurol (Chicago) 10: 98-115, 1964

9) Epstein AW: Primary massive pontine hemorrhage. A clinico-pathological study. $J$ Neuropath Exp Neurol 10: 426-448, 1951

10) Grindal AB, Suter C, Martinez AJ: Alpha-pattern coma. 24 cases with 9 survivors. Ann Neurol 1: 371-377, 1977

11）本藤秀樹, 吉田良順, 兽我部紘一郎, 上田 伸, 松本圭 蔵 : 脎血管障害による脳幹病柴 一臨床所見と CT 像一 脳卒中 $2 ： 355-363,1980$

12) Kaada BR, Harkmark W, Stokke O: Decp coma associated with desynchronization in EEG. Electroenceph Clin Neurophysiol 13: 785-789, 1961

13）金谷春之，山田孝文，小穴勝麿，奥寺利男：媨橋出血に 関吉臨床病理学的研究一特に自験症例とその文献的 考察一。譄と神 $20: 49-55,1968$

14) Kempe LG: Surgical removal of an intramedullary haematoma simulating Wallenberg's syndrome. I Neurol Neurasurg Psychiat 27: 78-80, 1964

15) 小林啓志, 外山 孚, 栗田 勇, 中井 吊, 佐藤 進 : 若年者の原発性橋出血. 脳と神 30:749-756, 1978

16) Koos WT, Sunder-Plassmann M, Salah S: Successful removal of a large intrapontine hematoma. Case report. $J$ Neurosurg $31: 690-694,1969$

17）古和田正悦, 估藤 勤：原発性橋出血の長期生存例の媨 波。臨遖波14:298-300, 1972

18）橨永㓮一，金田平夫，又野忠芳，種子田護，菱川泰夫： $\alpha$ 昏倕を呈した原発性脎幹出血に打ける脳波と $\mathrm{CT}$ 像. 臨神経21：179-187，1981

19）宮崎元沙：脳幹部病変に抒汁る脳波所見の臨床的意義 一徐波を中心とした考察—. 臨神経 $6 ： 445-452 ， 1966$

20) Müller HR, Wüthrich R, Wiggli U, Hünig R, Elke M: The contribution of computerized axial tomography to the diagnosis of cerebellar and pontine hematomas. Stroke $6: 467-475,1975$

21) Murphy MG: Successful evacuation of acute pontine hematoma. $J$ Neurosurg 37: 224-225, 1972

22）中島健二, 伊藤善太郎, 辺 龍秀, 鈴木明文, 深沢 1 : 橋出血の臨床病理学的研究 一II. 病理学的検討一. 譄と 神 $29: 1157-1165,1977$

23）中島健二, 伊藤善太郎, 鈴木一夫 : 橋出血軽症例. 譄と 神31：569-576, 1979

24）落合慈之, 佳野圭司, 小林 秀, 传々木富男, 真柳佳昭 : 橋出血の臨床的検討 一とくにCT 所見による分類と手 術適応について一。脳と神 31:803-811，1979

25) 大文英一, 亀山正邦：急性の脳幹障害之脳波。臨神経 6 : 88-94, 1966

26) 大友英一 : Spindle coma，臨脳波19:489-497，1977

27) Scott BB, Seeger JF, Schneider RC: Successful evacuation of a pontine hematoma secondary to rupture of a pathologically diagnosed "cryptic" vascular malformation. Case report. $J$ Neurosurg 39: 104-108, 1973

28) Silverstein A: Primary pontine hemorrhage, in Vinken PJ, Bruyn GW (eds): Handbook of Clinical Neurology, vol 12, Vascular Diseases of the Nervous System. Amsterdam, NorthHolland, 1972, pp 37-53

29) Steegmann AT: Primary pontile hemorrhage. With particular refcrence to respiratory failure. $I$ Neru Ment Dis 114: 35-65, 1951

30）田中靖通，西谷幹雄，小䇥原俊一，中村傾一，末松克美 : 高血圧性橋出血の䠛床的研 究. 脳と神 $34: 601-607$, 1982

31）渡辺口章：橋脳出血の病理，日病理会誌 $48: 1588-1616$, 1959

32）渡辺礼次郎：原発性媨橋出血の臨床病理学的研究. 臨神 経 $3: 94-112 ， 1963$

33) Westmoreland BF, Klass DW, Sharbrough FW, Rcagan TJ: Alpha-coma. Electroencephalographic, clinical, pathologic, and etiologic correlations. Arch Neurol (Chicago) 32: 713-718, $197 j$

34) Zuccarello $M$, Iavicoli $R$, Pardatscher $K$, Scanarini $M$, Fiore D, Andrioli GC: Primary brain stem haematomas. Diagnosis and treatment. Acta Neurochir (Wien) 54:45-52, 1980

〔別刷請求先： $\mathbf{\boldsymbol { T }} 690$ 島根県松江市母衣町 200, 松江赤十字病 院脑神経外科，桑原 敏] 